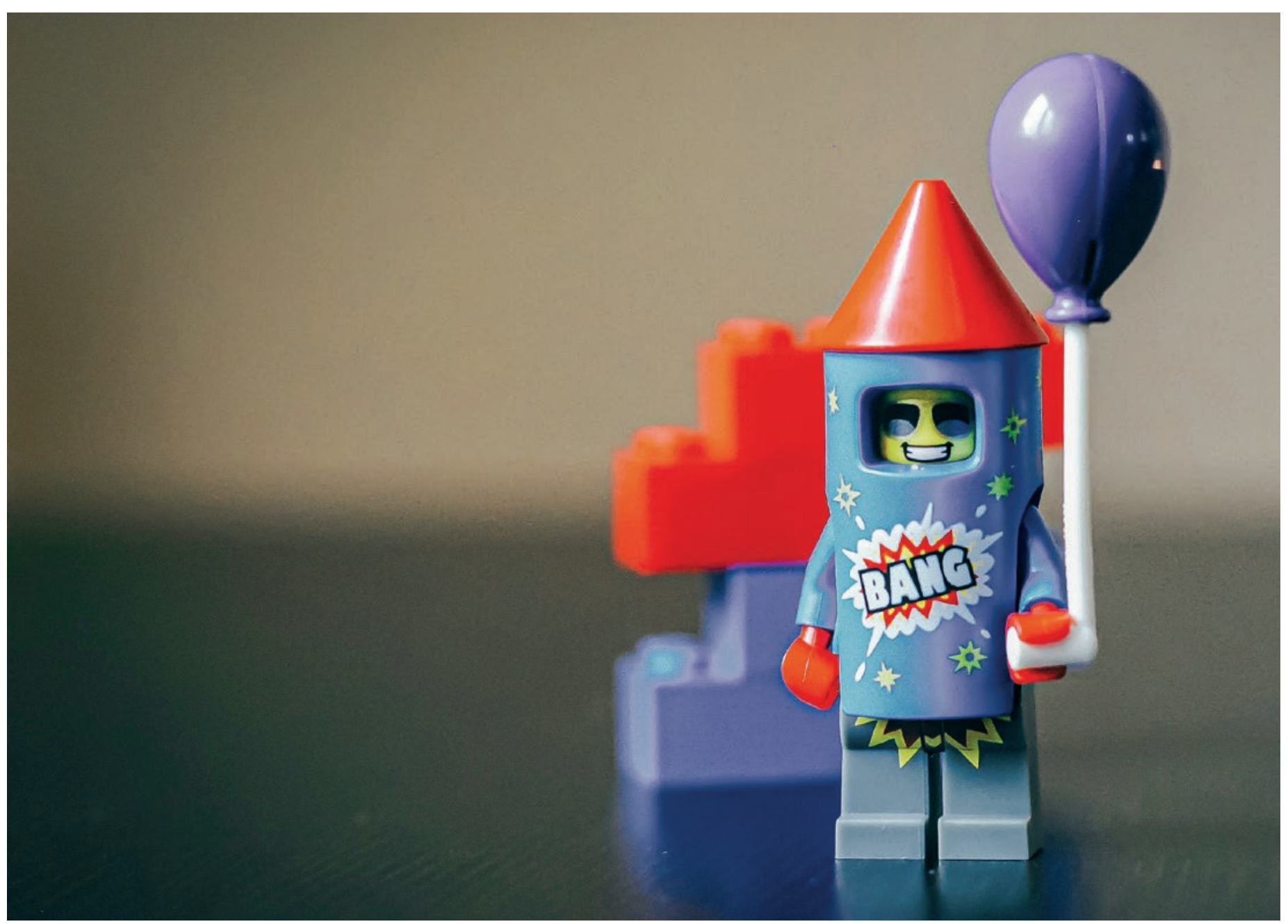

\title{
Mit der Raketenimpfung gegen das Coronavirus
}

\section{Eva Mell}

Managing Editor der Schweizerischen Ärztezeitung

Das Basler Start-up Rocketvax entwickelt einen neuartigen Impfstoff, der das Pandemiegeschehen verändern soll. Wie der Gründer Vladimir Cmiljanovic dem Immunsystem das vollständige Virus präsentieren will - und was Christoph Berger, Präsident der Eidgenössischen Kommission für Impffragen, von der Idee hält.

Vladimir Cmiljanovic will ein Pionier sein. Er ist überzeugt, dass er mit einer kühnen Idee einen Volltreffer landen kann: Der ehemalige Profihandballer und doktorierte Chemiker aus Basel entwickelt einen neuartigen Impfstoff gegen das Coronavirus SARS-CoV-2. Das Vakzin soll einen möglichst lange anhaltenden Schutz bieten, wie er im Gespräch sagt. Vielleicht sogar lebens- lang? Auf solch eine optimistische Prognose will sich Vladimir Cmiljanovic nicht festlegen. Das Ziel ist aber, dass die Bevölkerung nicht mehr regelmässig über Auffrischungsimpfungen nachdenken muss. Das Start-up, mit dem er das Pandemiegeschehen von der Schweiz aus verändern will, trägt den Namen Rocketvax, «Raketenimpfung». Vladimir Cmiljanovic will durchstarten. 


\section{Kooperationen und finanzielle Hilfen}

Abgehoben hat seine Rakete noch nicht, das Projekt befindet sich derzeit in der präklinischen Phase. Aber der Wahlschweizer konnte bereits einige Kooperationspartner überzeugen. Dazu gehören im Rahmen von Forschungskooperationen das Universitätsspital und die Universität Basel sowie das Schweizerische Tropenund Public Health-Institut in Basel. Der Kanton BaselStadt unterstützt Rocketvax mit derzeit einer Million Franken finanziell.

In einem kantonalen Gebäude neben dem Basler Münster sitzen die Impfstoffentwickler im Erdgeschoss. Über ihnen residiert die reformierte Kirche. Vladimir Cmiljanovic legt die Hände wie im Gebet zusammen, schaut nach oben und sagt augenzwinkernd: «Vielleicht hilft uns das ja.»

«Da das Virus mutiert, brauchen wir einen komplexeren Impfstoff als diejenigen, die es bereits gibt.»

Wobei eigentlich? Bei der Entwicklung eines Impfstoffs, der auf mehr setzen will als auf das Spikeprotein. Die bisherigen Impfstoffe präsentieren dem Immunsystem nur dieses Protein, gegen das der Körper nach der Impfung Antikörper bildet. Doch auf der Oberfläche des Coronavirus befinden sich noch weitere Proteine. «Da das Virus mutiert, brauchen wir einen komplexeren Impfstoff als diejenigen, die es bereits gibt", sagt Vladimir Cmiljanovic. Er will den Impfstoff der zweiten Generation entwickeln, der trotz Virusmutationen zuverlässigen Schutz bietet.

\section{Ein kastriertes Virus}

Seine Vorbilder sind die Vakzine gegen Masern, Polio und Gelbfieber. Bei diesen Impfungen wird das Immunsystem jeweils mit dem vollständigen Virus konfrontiert. Das will Vladimir Cmiljanovic auch bei der Impfung gegen SARS-CoV-2 erreichen. Die Kerntechnologie in Form von synthetischer DNA, die dem Impfstoffansatz teilweise zugrunde liegt, wird von dem ETH-Spin-off Gigabases Switzerland AG bereitgestellt. Das Team entfernt schliesslich die Replikationsproteine des Virus. "So haben wir ein kastriertes Virus, das sich nicht vermehren kann", sagt der Chemiker und Unternehmer.

Vladimir Cmiljanovic ist überzeugt von den Vorteilen, die sein Impfstoff bieten werde. Dazu gehört neben einer möglicherweise besonders guten Immunreaktion auch die unkomplizierte Lagerung des Vakzins, der nicht stark gekühlt werden müsse.

Noch hat die Phase-1-Studie nicht begonnen. Trotzdem: Wenn Vladimir Cmiljanovic von seinem Projekt erzählt, ist Aufbruchsstimmung zu hören und Hoffnung, die bald einer Gewissheit weichen soll. Aber ist das Raketenvakzin tatsächlich so vielversprechend?

\section{Harter Weg zum Erfolg}

Das Start-up verfolge ein interessantes Konzept, bestätigt Christoph Berger, Präsident der Eidgenössischen Kommission für Impffragen. «Das Vakzin ähnelt einem Lebendimpfstoff, kann sich aber nicht vermehren. Rocketvax hat das wirklich clever gemacht.» Der Impfstoff ähnelt dem natürlichen Virus stärker als die bisherigen Vakzine. «Das kann ein Vorteil sein, es kann aber auch Nachteile mit sich bringen", sagt Christoph Berger. Da Rocketvax das Immunsystem nicht nur mit dem Spikeprotein konfrontiere, werde der Impfstoff wahrscheinlich weniger Spikeproteine enthalten als die bisherigen. Das könnte zu geringeren Impf-Nebenwirkungen führen. "Aber gibt es dann eine genügend starke Reaktion des Immunsystems gegen das Spikeprotein?», gibt Berger zu bedenken. «Und könnte es nach der Impfung unangenehme Folgeerscheinungen geben, die durch andere Proteine des Virus ausgelöst werden? Wir wissen es nicht.»

«Könnte es nach der Impfung Folgeerscheinungen geben, die durch andere Proteine des Virus ausgelöst werden? Wir wissen es nicht.»

Viele Fragen seien noch offen, denn bisher wurden noch keine präklinischen Daten veröffentlicht. Die zugelassenen mRNA-Impfstoffe seien wirksam und sicher. Rocketvax müsse nun zeigen, dass der neue Impfstoff mindestens ebenso effektiv ist. «Der Ansatz ist innovativ", sagt Christoph Berger, aber der Weg zum Erfolg werde hart und steil.

Vladimir Cmiljanovic hat Kondition und Durchhaltevermögen. Das hat er schon in seiner Jugend als Profihandballer im Verein Bielefeld Jöllenbeck in Deutschland und beim RTV Basel gelernt. Jetzt braucht der Chemiker noch die passenden Forschungsergebnisse.

Bildnachweis

Hello I'm Nik / Unsplash 